\title{
PENGARUH PEMBERIAN LATIHAN FISIK JALAN KAKI TERHADAP PENURUNAN KADAR GULA DARAH PADA PENDERITA DM TIPE II DI KELURAHAN KUBU DALAM PARAK KARAKAH WILAYAH KERJA PUSKESMAS ANDALAS PADANG
}

\author{
Weny Amelia ${ }^{1}$, Zulham Efendi $^{2}$, Habil Habibi $^{3}$ \\ 1,2,3 Prodi S1 Keperawatan STIKes MERCUBAKTIJAYA Padang \\ Jl. Jamal Jamil Pondok Kopi Siteba Padang \\ Email*: wenyamelia.wa@gmail.com, zefendi59@yahoo.co.id, habilhabibi17@gmail.com
}

\begin{abstract}
Abstrak
Penyakit DM Tipe II adalah suatu keadaan hiperglikemia yang disebabkan gangguan pada resistensi insulin dan sekresi sehingga metabolisme tubuh juga terganggu. Pada DM Tipe II latihan fisik berperan sebagai pengatur dan mampu mengendalikan kadar gula darah. Salah satu latihan fisik yang dianjurkan pada pasien DM Tipe II adalah olahraga jalan kaki. Tujuan dari penelitian ini adalah untuk mengetahui pengaruh latihan fisik jalan kaki terhadap penurunan kadar gula darah pada pasien DM Tipe II.

Penelitian ini dilakukan di Kelurahan Kubu Dalam Parak Karakah Wilayah Kerja Puskesmas Andalas Padang. Waktu penelitian ini dimulai pada tanggal 29 Juni 2018 hingga 15 Juli 2018. Rancangan penelitian yang digunakan adalah quasi eksperiment dengan pendekatan time series design. Teknik pengambilan sampel adalah purposive sampling dengan sampel sebanyak 11 responden. Pengumpulan data dilakukan dengan pengukuran kadar gula darah sewaktu dengan intervensi latihan fisik jalan kaki selama 3 minggu. Analisa data dilakukan dengan uji Repeated Anova untuk melihat pengaruh intervensi.

Hasil penelitian menunjukkan adanya pengaruh penurunan kadar gula darah dengan melakukan latihan fisik jalan kaki pada minggu pertama terjadi penurunan $9.16 \mathrm{mg} / \mathrm{dl}$, minggu kedua $9.51 \mathrm{mg} / \mathrm{dl}$ dan minggu ketiga 12.94 $\mathrm{mg} / \mathrm{dl}$ dengan $\mathrm{p}$ - value $0.000(\mathrm{p}-0.05)$.

Dari hasil penelitian ini didapatkan bahwa adanya pengaruh latihan fisik jalan kaki yang dilakukan terhadap penurunan kadar gula darah pada penderita DM Tipe II. Saran untuk tenaga kesehatan agar memberikan pendidikan kesehatan tentang pentingnya latihan fisik jalan kaki untuk pengontrolan kadar gula darah dan juga pencegahan terjadinya komplikasi.
\end{abstract}

\section{Kata Kunci : Diabetes Melitus Tipe II, Jalan Kaki}

\begin{abstract}
DM Type II is a state of hyperglycemia caused by disorders of insulin resistance and secretion so that the body's metabolism is also disrupted. In DM Type II physical exercise acts as a regulator and is able to control blood sugar levels. One physical exercise recommended for Type II DM patients is walking exercise. The purpose of this study was to determine the effect of walking physical exercise on reducing blood sugar levels in Type II DM patients.

This research was carried out in Kubu Village in Parak Karakah Andalas Community Health Center Padang Work Area. The time of this study began on 29 June 2018 to 15 July 2018. The research design used was quasiexperimental with a time series design approach. The sampling technique was purposive sampling with a sample of 11 respondents. Data collection was carried out by measuring blood sugar levels when walking physical exercise interventions for 3 weeks. Data analysis was carried out by Repeated Anova test to see the influence of intervention.

The results showed the effect of a decrease in blood sugar levels by doing physical exercise walking in the first week there was a decrease of $9.16 \mathrm{mg} / \mathrm{dl}$, the second week $9.51 \mathrm{mg} / \mathrm{dl}$ and the third week $12.94 \mathrm{mg} / \mathrm{dl}$ with a p-value of $0.000(p-0.05)$.

From the results of this study it was found that there was an effect of walking physical exercise on reducing blood sugar levels in patients with Type II diabetes. Suggestions for health workers to provide health education about the importance of walking physical exercise to control blood sugar levels and also prevent the occurrence of complications.
\end{abstract}




\section{PENDAHULUAN}

Diabetes melitus (DM) merupakan kelompok kelainan heterogen yang ditandai oleh kenaikan kadar glukosa dalam darah atau hiperglikemia. Diabetes melitus dibedakan menjadi dua, yaitu diabetes melitus tipe I atau Insulin Dependent Diabetes Melitus (IDDM) dan diabetes melitus tipe II atau Non Insulin Dependent Diabetes Melitus (NIDDM) (Smeltzer \& Bare, 2010). DM tipe I terjadi karena pankreas tidak bisa memproduksi insulin. Pada DM tipe I ini terdapat sedikit atau tidak sama sekali sekresi, dan pada pasien yang menderita DM Tipe II adalah jika tubuhnya masih dapat memproduksi insulin, namun insulin yang dihasilkan tidak cukup atau sel lemak dan otot tubuh menjadi kebal terhadap insulin (American Diabetes Association, 2010).

DM tipe II adalah gangguan metabolisme dari sistem endokrin, terutama ditandai dengan ketidakseimbangan glikemik (American Diabetes Association, 2010). DM tipe II terjadi ketika pankreas tidak memproduksi insulin yang cukup untuk mempertahankan kadar glukosa darah normal atau ketika tubuh tidak mampu menggunakan insulin yang dihasilkan (resistensi insulin) (Almaido, 2015).

\section{International Diabetes Federation}

(IDF) menyebutkan bahwa prevalensi DM didunia adalah 1,9\% dan telah menjadikan DM sebagai penyebab kematian urutan ke tujuh didunia sedangkan tahun 2012 angka kejadian DM didunia adalah sebanyak 371 juta jiwa dimana proporsi kejadian DM tipe II adalah $95 \%$ dari populasi dunia yang menderita diabetes melitus (International Diabetes Federation (IDF) dalam Teixeria, 2011).

Hasil Riset Kesehatan Dasar pada tahun 2013, menunjukan prevalensi DM Tipe II di Indonesia berkisar sampai 57\% dengan jumlah penderita 2.6 juta jiwa. Sedangkan wilayah Sumatera Barat terdapat 1,32\% penderita DM Tipe II dari jumlah penduduk wilayah Sumatera Barat sebanyak 3,4 juta jiwa. Sedangkan di daerah kota Padang terdapat penderita DM Tipe II sebanyak 2,4\% dari jumlah penduduk kota Padang sebanyak 902.413 jiwa (DEPKES, 2013). Wilayah yang memiliki angka kejadian tertinggi di kota Padang adalah wilayah kerja Puskesmas Andalas Padang yaitu sebanyak 1860 penderita DM Tipe II dan data kunjungan tiga bulan terakhir sebanyak 432 pasien.

Tingginya prevalensi DM tipe II disebabkan oleh faktor resiko yang dapat diubah dan faktor resiko yang tidak dapat diubah. Faktor resiko yang dapat diubah adalah berat badan lebih, obesitas abdominal/sentral, kurangnya aktivitas fisik, hipertensi, diet tidak sehat dan tidak seimbang (tinggi kalori), riwayat Toleransi Gula Terganggu (TGT <140 - $199 \mathrm{mg} / \mathrm{dL}$ ) atau Gula Darah Puasa Terganggu (GDPT <140 $\mathrm{mg} / \mathrm{dL}$ ) dan merokok. Dan faktor resiko yang tidak dapat di ubah yaitu ras, dan etnik, umur, jenis kelamin, riwayat keluarga dengan diabetes melitus, riwayat melahirkan bayi dengan BB >4000 gram, riwayat lahir dengan berat badan lahir rendah/ BBLR <2500 gram (DEPKES, 2013).

Penanganan DM Tipe II dapat dikelompokan dalam empat pilar (PERKENI, 2011), yaitu edukasi, perencanaan makan, intervensi farmakologis dan latihan jasmani. Menurut hasil penelitian Achmad Yoga (2011) didapatkan hasil dan kesimpulan bahwa orang yang memiliki pengetahuan yang baik tentang DM Tipe II mempunyai kepatuhan dalam mengkonsumsi obat dan mempunyai pola makan yang baik memiliki tingkat keberhasilan sebanyak empat kali untuk berhasil dalam pengelolaan DM Tipe II dibandingkan dengan yang tidak memiliki 
pengetahuan yang baik, tidak patuh dalam mengkonsumsi obat dan tidak menjalankan pola makan yang sehat. Dalam penelitian ini juga membuktikan bahwa responden yang melakukan olahraga secara teratur dan baik memiliki keberhasilan pengelolaan DM Tipe II sebesar $40,1 \%$.

Sedangkan menurut Nurlaili dan Muhammad (2015) menunjukkan terdapat pengaruh empat pilar penatalaksanaan DM Tipe II terhadap rerata kadar gula darah. Sebagian besar responden yang memiliki pemahaman mengenai DM Tipe II mempunyai rerata kadar gula darah normal sebanyak 45,3\%, sedangkan responden dengan pengaturan makanan memiliki rerata kadar gula darah normal sebanyak 50,9\%, responden yang melakukan latihan jasmani (olahraga) memiliki rerata kadar gula darah normal sebanyak 50,9\% dan bagi responden dengan kepatuhan dalam minum obat memiliki rerata kadar gula darah normal sebanyak $41,5 \%$.

Latihan jasmani aktifitas dan olahraga merupakan salah satu pilar penatalaksanaan DM disamping edukasi, terapi gizi medis dan intervensi farmakologi. Manfaat latihan bagi penderita DM antara lain meningkatkan penurunan kadar glukosa darah, mencegah kegemukan, ikut berperan dalam mengatasi kemungkinan terjadinya komplikasi aterogenik, gangguan lemak darah, menormalkan tekanan darah, serta meningkatkan kemampuan kerja (Smeltzer \& Bare, 2010).

Ada banyak jenis olah raga yang dapat dilakukan untuk meningkatkan kesehatan tubuh. Tetapi jenis olah raga yang dianjurkan bagi penyandang DM adalah olah raga aerobic yang bertujuan untuk meningkatkan kesehatan dan kebugaran tubuh khususnya meningkatkan fungsi dan efisiensi metabolisme tubuh. Olah raga aerobic seperti jogging, berenang dan jalan kaki (Sudoyo, Setiyohadi, Alwi, Simadibrata, \& Setiati, 2009).

Salah satu jenis olah raga aerobic yang direkomendasikan untuk penderita DM Tipe II adalah jalan kaki. Dengan berjalan kaki setiap hari, selama 30 menit sampai satu jam dilakukan secara teratur 3-5 kali perminggu. Penderita DM Tipe II mendapatkan banyak manfaat, yaitu meningkatkan kontrol glukosa. Latihan ini membantu otot menyerap gula darah, dan mencegahnya bertambah dalam aliran darah, dan juga membantu mengatur berat badan (Sudoyo, Setiyohadi, Alwi, Simadibrata, \& Setiati, 2009).

Berdasarkan hasil penelitian yang dilakukan oleh (Puji, Heru, \& Agus, 2008) menunjukan bahwa setelah melakukan senam aerobic rata - rata kadar gula darahnya menjadi 210,14 mg\% dengan standar deviasi $15,93 \mathrm{mg} \%$ dan setelah dilakukan perlakuan terjadi penurunan kadar gula darah sebesar 30,14 mg\%. Penelitian ini menunjukan adanya pengaruh latihan senam aerobic terhadap penurunan kadar gula darah pada penderita DM Tipe II $(\mathrm{p}=0,0001)$.

Olahraga latihan fisik jalan kaki terapi terbaik untuk mencegah DM dan sindrom metabolik. Sejumlah studi yang telah meneliti peran aktivitas fisik dan latihan dalam DM Tipe II menunjukkan manfaat yang jelas dari aktifitas fisik dan latihan dalam penatalaksanaan DM Tipe II. Program pencegahan Diabetes Research Group menunjukan bahwa setidaknya seratus lima puluh menit perminggu latihan fisik intensitas sedang sebagai bagian dari intervensi gaya hidup secara nyata dapat menurunkan perkembangan DM Tipe II (Gordon et. al, 2008).

Latihan fisik juga memberikan efek lainnya pada tubuh yaitu menurunkan berat badan karena saat latihan fisik terjadi pembakaran lemak dan karbohidrat, 
meningkatkan fungsi kardiovaskuler dan respirasi dimana efektifitas kerja jantung meningkat dan kapasitas paru - paru juga meningkat, menurunkan kolesterol lipoprotein berkepadatan rendah atau low density lipoprotein cholesterol (LDL) dan meningkatkan kolesterol lipoprotein berkepadatan tinggi atau high density lipoprotein cholesterol (HDL) sehingga mencegah penyakit jantung koroner, merangsang hormon epinefrin dan norepinefrin sehingga dapat menurunkan tekanan darah, mengurangi kebutuhan pemakaian obat oral dan insulin, dan mencegah terjadinya DM yang dini terutama bagi orang - orang dengan riwayat keluarga penyandang DM atau bagi yang masuk dalam golongan pre-DM. Latihan fisik akan bermanfaat sekali apabila dilakukan secara benar dan teratur (Setyanto, 2009).

Banyaknya manfaat dari latihan fisik jalan kaki, maka latihan fisik sangat penting dianjurkan kepada penyandang DM. Sebagaimana berdasarkan penelitian yang telah dilakukan sebelumnya oleh (Indriyani, Supriyatno, \& Santoso, 2009) menunjukan bahwa setelah melakukan jalan kaki selama 30 menit sampai satu jam dilakukan secara teratur 3-5 kali per-minggu rata - rata kadar gula darahnya menjadi $210,14 \mathrm{mg} \%$ dengan standar deviasi $15,93 \mathrm{mg} \%$ dan setelah dilakukan perlakuan terjadi penurunan kadar gula darah sebesar 30,14 mg\%. Penelitian ini menunjukan adanya pengaruh latihan fisik : jalan kaki terhadap penurunan kadar gula darah pada penderita DM Tipe $2(\mathrm{p}=0,0001)$. Jadi memang terlihat bahwa latihan fisik dapat berpengaruh terhadap penurunan kadar gula darah bagi seseorang yang menderita penyakit DM (Indriyani, Supriyatno, \& Santoso, 2009).

\section{METODE PENELITIAN}

Penelitian ini merupakan quasi eksperimental design dengan mengunakan pendekatan time series design. Dalam penelitian ini sampel berjumlah 11 orang.

Instrumen yang digunakan yaitu, lembar observasi. Lembar observasi digunakan untuk mengobservasi jalan kaki dan pencatatan kadar gula darah responden. Selain itu untuk mengukur kadar gula darah responden digunakan juga Blood Glucose Test Meter, glucocard x-sensor, lancing device, lancets, kassa steril dan alcohol swab. Uji analisis yang digunakan pada penelitian ini adalah Repeated ANOVA.

\section{HASIL DAN PEMBAHASAN}

\section{Rerata Kadar Gula Darah Sebelum Melakukan Latihan fisik jalan kaki pada penderita DM Tipe II}

\begin{tabular}{lccc}
\hline $\begin{array}{l}\text { Kadar Gula } \\
\text { Darah }\end{array}$ & $\begin{array}{c}\text { Mean } \\
(\mathrm{mg} / \mathrm{dl})\end{array}$ & $\begin{array}{c}\text { SD } \\
(\mathrm{mg} / \mathrm{dl})\end{array}$ & $\begin{array}{c}\text { Min - Max } \\
(\mathrm{mg} / \mathrm{dl})\end{array}$ \\
\hline $\begin{array}{c}\text { Sebelum } \\
\text { Latihan Fisik } \\
\text { Jalan Kaki }\end{array}$ & 255.36 & 5.06 & $250-266$ \\
\hline
\end{tabular}

Hasil analisis pada tabel diatas didapatkan data rata - rata kadar gula darah sebelum melakukan latihan fisik jalan kaki adalah $255.36 \mathrm{mg} / \mathrm{dl}$ dengan standar deviasi 5.06, dengan kadar gula terendah $250 \mathrm{mg} / \mathrm{dl}$ dan kadar gula tertinggi $266 \mathrm{mg} / \mathrm{dl}$.

Penelitian ini sesuai dengan penelitian yang dilakukan oleh Puji (2010) yang juga menyatakan bahwa tingkat rerata kadar gula darah pretest responden sebesar $274.43 \mathrm{mg} / \mathrm{dl}$.

Tingginya kadar gula darah tersebut dipengaruhi oleh beberapa faktor salah satunya gaya hidup yang tidak sehat seperti kurangnya aktivitas fisik. Latihan fisik yang teratur dapat meningkatkan kualitas pembulu darah dan memperbaiki semua aspek 
metabolik termasuk meningkatkan kepekaan insulin serta memperbaiki toleransi glukosa darah. Hasil penelitian di Indian Pima, diketahui rata - rata kadar gula darah sebelum dilakukan aktivitas fisik adalah $249 \mathrm{mg} / \mathrm{dl}$ dan sesudah aktivitas fisik dilakukan adalah 215 $\mathrm{mg} / \mathrm{dl}$ sehingga diambil kesimpulan orang orang yang aktivitas fisiknya rendah 2.5 kali lebih beresiko mengalami DM (Radio, 2011).

Menurut analisa peneliti kadar gula darah juga dipengaruhi oleh latihan fisik. Latihan fisik juga dapat meningkatkan ambilan glukosa oleh otot dan tubuh menjadi lebih sensitif terhadap insulin. Latihan fisik yang dilakukan secara teratur dapat menurunkan kadar gula darah, salah satu satu latihan fisik yang disarankan adalah jalan kaki yang merupakan salah satu pilar dari pengelolaan DM Tipe II.

\section{Rerata kadar gula darah sesudah melakukan latihan fisik jalan kaki pada penderita DM Tipe II}

\begin{tabular}{|c|c|c|c|c|}
\hline $\begin{array}{l}\text { Kadar } \\
\text { Gula } \\
\text { Darah }\end{array}$ & $\begin{array}{c}\text { Mean } \\
(\mathrm{mg} / \mathrm{dl})\end{array}$ & $\begin{array}{c}\mathrm{SD} \\
(\mathrm{mg} / \\
\mathrm{dl})\end{array}$ & $\begin{array}{c}\text { Min - } \\
\text { Max } \\
\text { (mg/dl) }\end{array}$ & $\begin{array}{c}\text { Penuru } \\
\text { nan } \\
(\mathrm{mg} / \mathrm{dl} \\
)\end{array}$ \\
\hline $\begin{array}{c}\text { Sesudah } \\
\text { Latihan } \\
\text { Fisik } \\
\text { Jalan } \\
\text { Kaki }\end{array}$ & 223.54 & 7.59 & $\begin{array}{c}223- \\
238\end{array}$ & 13.36 \\
\hline
\end{tabular}

Berdasarkan hasil penelitian menunjukkan bahwa kadar gula darah rata rata responden setelah melakukan latihan fisik jalan kaki pada minggu pertama adalah $246.54 \mathrm{mg} / \mathrm{dl}$. Dengan kadar gula terendah $237 \mathrm{mg} / \mathrm{dl}$ dan kadar gula darah tertinggi 259 $\mathrm{mg} / \mathrm{dl}$. Dengan standar deviasi 7.09. Pada saat dilakukan pengukuran minggu kedua didapatkan kadar gula rata - rata $236.9 \mathrm{mg} / \mathrm{dl}$ dengan kadar gula darah terendah $224 \mathrm{mg} / \mathrm{dl}$ dan kadar gula darah tertinggi $250 \mathrm{mg} / \mathrm{dl}$ dengan standar deviasi 6.86. Dan pada saat dilakukan pengukuran kadar gula darah minggu ketiga rata - rata kadar gula darah adalah $223.54 \mathrm{mg} / \mathrm{dl}$ dengan kadar gula darah terendah $212 \mathrm{mg} / \mathrm{dl}$ dan kadar gula darah tertinggi $238 \mathrm{mg} / \mathrm{dl}$ dengan standar deviasi 7.59 .

Pada saat pretest kadar gula darah rata - rata adalah $255.36 \mathrm{mg} / \mathrm{dl}$ kemudian dilakukan intervensi selama 3 hari berturut turut yaitu hari Jumat, Sabtu dan Minggu, kemudian dilakukan pengukuran kadar gula darah pada minggu pertama dan didapatkan kadar gula rata - rata $246.54 \mathrm{mg} / \mathrm{dl}$. Hasil pengukuran pada minggu pertama terjadi penurunan rata - rata kadar gula darah sebanyak $8.82 \mathrm{mg} / \mathrm{dl}$. Kemudian dilanjutkan intervensi minggu kedua didapatkan hasil pengukuran rata - rata kadar gula darah mengalami penurunan sebanyak $9.64 \mathrm{mg} / \mathrm{dl}$ dan saat pengukuran kadar gula darah pada minggu ketiga didapatkan kembali rata - rata kadar gula darah yang turun, diperoleh hasil $13.36 \mathrm{mg} / \mathrm{dl}$.

Berdasarkan penelitian yang telah dilakukan didapatkan bahwa responden yang melakukan latihan jalan kaki terjadi penurunan kadar gula darah yang berbeda beda pada masing - masing responden. Hal ini sesuai dengan Harun (2008 dikutip dari Lenggogeni, 2010) bahwa penurunan kadar gula darah tersebut berbeda - beda pada setiap respondennya. Setiap subjek penelitian akan menjadi kontrol terhadap dirinya sendiri, hal itulah yang menyebabkan terjadinya perbedaan perubahan kadar gula darah.

Dilihat dari karakteristik responden, diketahui bahwa responden terbanyak yang mengikuti latihan fisik jalan kaki adalah responden yang berumur 41 - 50 tahun sebanyak 4 orang dan $51-60$ tahun 4 orang. 
Menurut Sudoyo (2009) kejadian DM Tipe II mencapai puncaknya pada usia 40 tahun karena kelompok usia diatas 40 tahun mempunyai resiko tinggi terkena DM Tipe II akibat penurunan toleransi glukosa yang berhubungan dengan berkurangnya sensitifitas sel perifer terhadap efek insulin.

Dari karakteristik jenis kelamin terlihat bahwa sebagian besar responden berjenis kelamin perempuan yang menderita DM Tipe II yaitu sebanyak 8 orang (73\%). Menurut Indriyani (2009) pada usia 40-70 tahun DM Tipe II lebih banyak terjadi pada wanita, tetapi pada umur yang lebih muda frekuensi diabetes lebih besar dari pada pria. Hal ini juga dipicu oleh adanya persentase timbunan lemak badan pada wanita lebih besar dibandingkan dengan laki - laki yang dapat menurunkan sensitifitas terhadap kerja otot dan hati.

Pada karakteristik pekerjaan sebanyak 5 orang responden adalah ibu rumah tangga, 3 responden adalah wiraswasta, dan 3 responden adalah pensiunan. Pekerjaan memiliki dampak yang penting dalam upaya meminimalisirkan seseorang dalam terkena penyakit. Pekerjaan sebagai ibu rumah tangga identik dengan pekerjaan yang cukup ringan dibandingkan dengan pekerjaan lainnya. Pekerjaan tersebut umumnya tidak banyak mengeluarkan keringat karena tidak banyak aktifitas dan lebih sedikit menggunakan otot. Secara umum ibu rumah tangga lebih banyak terkena penyakit DM karena umumnya olah fisik yang lebih sedikit dan perempuan juga lebih rentan terkena diabetes (Slamet, 2011).

\section{Pengaruh latihan fisik jalan kaki terhadap penurunan kadar gula darah pada penderita DM Tipe II}

\begin{tabular}{cccc}
\hline & & Mean Difference & p value \\
\hline \multirow{3}{*}{ PreTest } & Post Test M 1 & 8.818 & 0.000 \\
\cline { 2 - 4 } & Post Test M 2 & 18.455 & 0.000 \\
\cline { 2 - 4 } & Post Test M 3 & 31.818 & 0.000 \\
\hline
\end{tabular}

Berdasarkan hasil penelitian yang telah dilakukan di Kelurahan Kubu Dalam Parak Karakah Wilayah Kerja Puskesmas Andalas Padang, pada perbandingan pertama yaitu Pretest dengan Post Test M 1 terdapat perbedaan rerata kadar gula darah yaitu sebesar $8.818 \mathrm{mg} / \mathrm{dl}$ dengan nilai signifikan 0.000 . Sedangkan perbandingan kedua yaitu Pretest dengan Post Test M 2 terdapat perbedaan rerata kadar gula darah yaitu sebesar $18.455 \mathrm{mg} / \mathrm{dl}$ dengan nilai signifikan 0.000. Dan perbandingan ketiga yaitu Pretest dengan Post Test M 3 terdapat perbedaan rerata kadar gula darah yaitu sebesar 31.818 $\mathrm{mg} / \mathrm{dl}$ dengan nilai signifikan 0.000 .

Menurut penelitian yang dilakukan oleh Fitri dan Yekti menunjukkan pelaksanaan latihan jasmani dapat menurunkan kadar gula darah, memperbaiki profil lemak, menurunkan tekanan darah, mencegah dan mengatasi kegemukan pada penderita DM Tipe II. Penurunan kadar gula darah ini berkaitan dengan peningkatan jumlah dan sensitifitas reseptor insulin pada membran sel sehingga terjadi penurunan kebutuhan insulin sebanyak $30-50 \%$ pada penderita DM Tipe I dan $100 \%$ pada penderita DM Tipe II (Fitri \& Yekti, 2012).

Latihan fisik jalan kaki yang dilakukan responden nantinya akan mengakibatkan peningkatan kebutuhan bahan bakar tubuh oleh otot yang aktif. Pada latihan fisik jalan kaki juga akan terjadi reaksi tubuh 
yang kompleks meliputi fungsi sirkulasi, metabolisme, pelepasan dan pengaturan hormonal dan susunan saraf otonom. Pada keadaan istirahat metabolisme otot hanya sedikit sekali memakai glukosa sebagai sumber bahan bakar sedangkan pada saat berolahraga glukosa dan lemak merupakan sumber energi utama (Brian, 2013).

Mekanisme regulasi ambilan glukosa disebabkan adanya pelepasan bradikinin yang dipacu oleh insulin pada otot yang sedang bergerak, sehingga ambilan glukosa oleh otot bertambah dan ambilan glukosa oleh otot yang tidak berkontraksi ikut meningkat.

Kegiatan fisik pada keadaan post absorbsi makanan, maka kebutuhan energi otot yang bekerja akan dipenuhi oleh proses pemecahan glikogen intramuscular, cadangan trigliserida dan juga peningkatan sediaan glukosa dan asam lemak bebas dari trigliserida ekstramuskular (Sudoyo, 2009). Ambilan glukosa oleh jaringan pada keadaan istirahat membutuhkan insulin. Sedangkan pada otot yang aktif, walaupun terjadi peningkatan kebutuhan glukosa, tapi kadar tidak meningkat. Hal ini disebabkan karena peningkatan kepekaan reseptor insulin otot dan pertambahan reseptor insulin otot pada saat melakukan latihan fisik. Pada latihan fisik akan terjadi peningkatan aliran darah, menyebabkan lebih banyak jala - jala kapiler terbuka sehingga lebih banyak tersedia reseptor insulin dan reseptor menjadi lebih aktif (Sudoyo, 2009).

Penurunan kadar gula darah ini terjadi karena ketika jalan kaki dilakukan maka akan terjadi kontraksi antar otot skeletal yang dapat mempengaruhi peningkatan kemampuan insulin untuk mengaktivasi transpor gula ke otot melalui jalur independen insulin sehingga terjadi penurunan level plasma glukosa. Otot juga mengalami adaptasi tambahan berupa terjadinya sintesis heksokinase II sehingga insulin meningkat, glukosa ditranspor ke sel , kadar gula darah menurun dan dihasilkan energi (Gulve, 2008).

Menurut analisa peneliti, pemberian intervensi jalan kaki memiliki efektifitas terhadap penurunan kadar gula darah pada penderita DM Tipe II, Dari penjelasan diatas dapat disimpulkan bahwa dengan melakukan latihan fisik jalan kaki dapat menurunkan kadar gula darah pada DM Tipe II. Hal ini disebabkan karena peningkatan kepekaan reseptor insulin otot dan pertambahan reseptor insulin otot pada saat melakukan latihan fisik. Pada latihan fisik akan terjadi peningkatan aliran darah, menyebabkan lebih banyak jala - jala kapiler terbuka sehingga lebih banyak tersedia reseptor insulin dan reseptor menjadi lebih aktif. Penurunan kadar gula darah ini juga berkaitan dengan peningkatan jumlah dan sensitifitas reseptor insulin pada membran sel sehingga terjadi penurunan kebutuhan insulin sebanyak $100 \%$ pada penderita DM Tipe II.

\section{KESIMPULAN}

Berdasarkan hasil penelitian yang telah dilakukan oleh peneliti mendapatkan kesimpulan sebagai berikut :

1. Rata - rata kadar gala gula darah responden sebelum dilakukan intervensi $255.36 \mathrm{mg} / \mathrm{dl}$.

2. Rata - rata kadar gula darah pada DM Tipe II setelah dilakukan intervensi didapatkan penurunan pada minggu pertama $246.54 \mathrm{mg} / \mathrm{dl}$, minggu kedua $236.9 \mathrm{mg} / \mathrm{dl}$ dan minggu ketiga 223.54 $\mathrm{mg} / \mathrm{dl}$.

3. Terdapat pengaruh latihan fisik jalan kaki terhadap penurunan kadar gula darah pada penderita DM Tipe II di Kelurahan Kubu Dalam Parak Karakah wilayah kerja Puskesmas Andalas Padang. 


\section{UCAPAN TERIMAKASIH}

Peneliti menyampaikan ucapan terima kasih yang sedalam-dalamnya kepada yang terhormat:

1. Kepala Puskesmas Andalas Padang beserta staf yang telah memberi izin untuk melakukan penelitian di Wilayah Kerja Puskesmas Andalas Padang.

2. Responden yang berada di Kelurahan Kubu Dalam Parak Karakah Wilayah Kerja Puskesmas Andalas Padang yang telah bersedia menjadi Responden.

3. Ibu Hj. Elmiyasna K., S.Kp., MM sebagai ketua STIKes MERCUBAKTIJAYA Padang.

4. Bapak Jasmarizal SKp, MARS sebagai ketua Yayasan STIKes MERCUBAKTIJAYA Padang.

5. Semua pihak yang telah memberi dukungan, bantuan dan motivasi dalam segala hal dalam penyelesaian penelitian ini

\section{DAFTAR PUSTAKA}

Achmad Yoga, S. U. (2011). Hubungan Antara Empat Pilar Pengelolaan Diabetes Melitus dengan Keberhasilan Pengelolaan Diabetes Melitus Tipe 2. Artikel Karya Tulis Ilmiah.

Almaido, P. (2015). Health Education in The Management of Diabetes at The Primary Health Care Level. Eastern Mediterranean Health Journal .

American Diabetes Association, (. (2010). Standards of Medical Care In Diabetes. Diabetes Care.

Brian J, S. (2013). Fitness Illustrated. Montana: Human Kinetics.

DEPKES, R. (2013). Situasi dan Analisis Diabetes. InfoDATIN.

Indriyani, P., Supriyatno, H., \& Santoso, A. (2009). Pengaruh Latihan Fisik Aerobic Terhadap Penurunan Kadar Gula Darah. Media Ners.

Nurlaili, H. K., \& Muhammad, A. I. (2015). Hubungan Empat Pilar Pengendalian
Dm Tipe 2 Dengan Rerata Kadar Gula Darah. Jurnal Berkala Epidemiologi, 234-243.

PERKENI, P. E. (2011). Konsensus Pengelolaan dan Pencegahan Diabetes Melitus Tipe 2. Perkeni.

PERKENI. (2011). Konsensus Pengelolaan Diabetes Tipe II di Indonesia . $P B$ PERKENI.

Puji, I., Heru, S., \& Agus, S. (2008). Pengaruh Latihan Fisik Senam Aerobik Terhadap Penurunan Kadar Gula Darah Pada Penderita DM Tipe 2 Diwilayah Puskesmas Bukateja Purbalingga . Media Ners , 49-99.

RISKESDAS. (2013). Badan Penelitian dan Pengembangan Kesehatan Kementerian Kesehatan RI. Jakarta: Kemenkes RI.

S. A. (2009). Buku Ajar Ilmu Penyakit Dalam edisi 5. Jakarta: Interna.

Smeltzer, S., \& Bare, B. (2010). Buku Ajar Keperawatan Medikal Bedah. Jakarta: EGC.

Sudoyo, A., Setiyohadi, B., Alwi, I., Simadibrata, M., \& Setiati, S. (2009). Buku Ajar Ilmu Penyakit Dalam Jilid II Edisi 5. Jakarta: Interna Publishing.

Teixeria, L. (2011). Regular Physical Exercise Training Assist In Preventing Type II Diabetes Development. Biomed Central Cardiovascular Diabetology.

Tjokroprawiro, A. (2011). Diabetes Melitus Klasifikasi, Diagnosis, dan Terapi. Jakarta: Gramedia Pustaka Utama. 